\title{
Cardiorespiratory effects of protamine after cardiopulmonary bypass in man
}

\author{
J. JASTRZEBSKI, M. K. SYKES, and D. G. WOODS \\ Institute of Haematology, Warsaw, Department of Anaesthetics, Royal Postgraduate Medical School, and \\ Anaesthetic Department, Hammersmith Hospital, Du Cane Road, London W12 OHS
}

\begin{abstract}
Jastrzebski, J., Sykes, M. K., and Woods, D. G. (1974). Thorax, 29, 534-538. Cardiorespiratory effects of protamine after cardiopulmonary bypass in man. The cardiorespiratory changes following the injection of protamine sulphate $(6 \mathrm{mg} / \mathrm{kg}$ ) were studied in 15 patients who had undergone cardiopulmonary bypass. There was a transient fall in arterial pressure and a more prolonged increase in pulmonary artery pressure. There was a significant fall in arterial oxygen tension which was mainly due to a reduction in mixed venous oxygen tension resulting from a fall in cardiac output. Dead space/tidal volume ratio and percentage shunt did not change significantly.
\end{abstract}

There is commonly a marked fall in arterial blood pressure when protamine is administered after cardiopulmonary bypass. This is but one manifestation of a series of changes which appear to result from the release of vasoactive substances from the platelet in response to the injection of protamine. In dogs, Rådegran and McAslan (1972) found that protamine infusion produced a fall in platelet count and a fall in aortic blood pressure and systemic vascular resistance while pulmonary artery pressure and resistance increased. Lung compliance decreased, airway resistance increased, and there was a fall in arterial oxygen tension. Although some of the cardiovascular changes have been documented in man, we have been unable to find any report detailing changes in lung function after the injection of protamine. This paper describes the effects of protamine on gas exchange in the lung after openheart surgery.

\section{METHODS}

Fifteen patients were studied during the period immediately following cardiopulmonary bypass. Details of the patients and heparin and protamine dosages are given in Table I. Heparin was given in an initial dose of $3 \mathrm{mg} / \mathrm{kg}$ followed by $1.5 \mathrm{mg} / \mathrm{kg}$ every hour. Protamine was given in a dose of $6 \mathrm{mg} / \mathrm{kg}$ when major surgical haemorrhage had been controlled. All the patients were premedicated with omnopon and scopolamine and anaesthetized with thiopentone, pancuronium, nitrous oxide, and phenoperidine. A cuffed oral tube was inserted and mechanical ventilation was provided by an Engström ventilator set at 20 breaths per minute, the tidal volume being adjusted to provide an arterial $\mathrm{PCO}_{2}$ of $30-4 \mathrm{QP}$ $\mathrm{mmHg}$. Inspired gases were humidified with a hot wates humidifier except during the period of study. An end? expiratory pressure of $5-10 \mathrm{cmH}_{2} \mathrm{O}$ was applied as soon as the chest was open and maintained until the chest waso closed.

Just before perfusion was discontinued, a further dose of phenoperidine was given and a collect valve wasinterposed between the patient $\mathrm{Y}$-piece and the endo tracheal tube (Sykes, 1969a). The lungs were then hyper inflated several times to $+40 \mathrm{cmH}_{2} \mathrm{O}$ by occluding the expiratory port of the collect valve, and the plateau of airway pressure was observed to ensure that no leaks were present. The expiratory port on the valve was then connected to a Wright's respirometer, a weight-operated. end-expiratory pressure valve, a gas-mixing unit (Sykes,? 1968), and a calibrated dry gas meter. The collect valve separated gas compressed in the ventilator tubing fromp true expired gas, while the Wright's respirometer was used to check that there was no leakage of inspired gas through the expiratory port during inspiration.

When perfusion was discontinued the inspired gas mixture was changed to $30 \%$ oxygen in nitrogen and the expired volume was adjusted to a value which was approxi mately $1 \mathrm{l} / \mathrm{min}$ more than that required to maintain $\mathrm{aW}$ normal $\mathrm{PCO}_{2}$ before bypass (Pauca and Sykes, 1966) The aortic perfusion cannula was removed as soon a\&o cardiovascular stability had been achieved, and the firs set of measurements was made when major surgicaks haemorrhage had been controlled. Protamine $(6 \mathrm{mg} / \mathrm{kg})$ was then injected over a period of about 5 minutes and the second set of measurements was made 5 minutes after the end of the injection. The third set of measurements? was made 15 minutes after the end of the injection.

Arterial samples were obtained from the radial artery line and pulmonary arterial samples were obtained by 
T A B L E I

\begin{tabular}{|c|c|c|c|c|c|c|c|c|c|c|}
\hline $\begin{array}{l}\text { Age } \\
\text { (yr) }\end{array}$ & $\begin{array}{c}\text { Weight } \\
\text { (kg) }\end{array}$ & $\begin{array}{c}\text { Height } \\
\text { (cm) }\end{array}$ & $\begin{array}{c}\text { Body } \\
\text { Surface } \\
\text { Area } \\
\left(\mathrm{m}^{2}\right)\end{array}$ & Diagnosis & Operation & $\underset{\text { (mg) }}{\text { Heparin }}$ & $\underset{(\mathrm{mg})}{\text { Protamine }}$ & $\begin{array}{c}\text { Duration } \\
\text { of } \\
\text { Bypass }\end{array}$ & $\underset{\left(\mathrm{cmH}_{2} \mathrm{O}\right)}{\text { PEEP }}$ & Result \\
\hline $\begin{array}{l}99 \\
41 \\
31 \\
44 \\
62 \\
58 \\
53 \\
61 \\
46 \\
64 \\
32 \\
18 \\
42\end{array}$ & $\begin{array}{l}38 \\
63 \\
67 \\
53 \\
75 \\
71 \\
43 \\
54 \\
58 \\
53 \\
45 \\
58 \\
46\end{array}$ & $\begin{array}{l}100 \\
165 \\
158 \\
165 \\
134 \\
163 \\
150 \\
167 \\
160 \\
154 \\
149 \\
183 \\
163\end{array}$ & $\begin{array}{l}0.96 \\
1.72 \\
1.70 \\
1.60 \\
1.47 \\
1.75 \\
1.30 \\
1.60 \\
1.56 \\
1.49 \\
1 \cdot 35 \\
1.76 \\
1.42\end{array}$ & $\begin{array}{l}\text { Fallot's tetralogy } \\
\text { MI and MS } \\
\text { AI } \\
\text { MI and TI } \\
\text { AI } \\
\text { Coronary ischaemia } \\
\text { MI } \\
\text { MI } \\
\text { MI } \\
\text { AI } \\
\text { AI and MI } \\
\text { Marfan's syndrome } \\
\text { MI and MS }\end{array}$ & $\begin{array}{l}\text { Complete repair } \\
\text { MVR } \\
\text { AVR } \\
\text { MVR and TVR } \\
\text { AVR } \\
\text { Vein graft } \\
\text { MVR } \\
\text { MVR } \\
\text { MVR } \\
\text { AVR } \\
\text { MVR and AVR } \\
\text { AVR } \\
\text { MVR and tricuspid }\end{array}$ & $\begin{array}{l}115 \\
332 \\
250 \\
308 \\
225 \\
330 \\
132 \\
243 \\
252 \\
150 \\
260 \\
360 \\
250\end{array}$ & $\begin{array}{l}150 \\
380 \\
400 \\
312 \\
300 \\
440 \\
260 \\
324 \\
340 \\
300 \\
280 \\
360 \\
280\end{array}$ & $\begin{array}{l}1 \mathrm{hr} 10 \mathrm{~min} \\
2 \mathrm{hr} 4 \mathrm{~min} \\
1 \mathrm{hr} 19 \mathrm{~min} \\
2 \mathrm{hr} 14 \mathrm{~min} \\
1 \mathrm{hr} 20 \mathrm{~min} \\
51 \mathrm{~min} \\
1 \mathrm{hr} 25 \mathrm{~min} \\
1 \mathrm{hr} 50 \mathrm{~min} \\
1 \mathrm{hr} 16 \mathrm{~min} \\
1 \mathrm{hr} 27 \mathrm{~min} \\
2 \mathrm{hr} 42 \mathrm{~min} \\
4 \mathrm{hr} 25 \mathrm{~min} \\
1 \mathrm{hr} 50 \mathrm{~min}\end{array}$ & $\begin{array}{r}0 \\
10 \\
10 \\
8 \\
8 \\
5 \\
8 \\
7 \\
8 \\
7 \\
9 \\
10 \\
10\end{array}$ & $\begin{array}{l}\mathbf{S} \\
\mathbf{S} \\
\mathbf{S} \\
\mathbf{S} \\
\mathbf{S} \\
\mathbf{S} \\
\mathbf{S} \\
\mathbf{S} \\
\mathbf{S} \\
\mathbf{S} \\
\mathbf{D} \\
\mathbf{S} \\
\mathbf{S}\end{array}$ \\
\hline $\begin{array}{l}41 \\
14\end{array}$ & $\begin{array}{l}57 \\
65\end{array}$ & $\begin{array}{l}160 \\
158\end{array}$ & $\begin{array}{l}1.58 \\
1.65\end{array}$ & $\begin{array}{l}\text { MI } \\
\text { ASD }\end{array}$ & $\begin{array}{l}\text { annuloplasty } \\
\text { MVR } \\
\text { ASD closure }\end{array}$ & $\begin{array}{l}265 \\
195\end{array}$ & $\begin{array}{l}340 \\
390\end{array}$ & 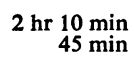 & $\begin{array}{l}8 \\
8\end{array}$ & $\stackrel{\mathbf{S}}{\mathbf{S}}$ \\
\hline
\end{tabular}

MS, MI, MVR = mitral valve stenosis, incompetence, valve replacement.

$\mathbf{A I}, \mathbf{A V R}=$ aortic valve incompetence, valve replacement.

TI, TVR = tricuspid valve incompetence, valve replacement.

ASD = atrial septal defect.

$\mathrm{S}=$ survived; $\mathbf{D}=$ died.

T A B L E I I

CARDIORESPIRATORY CHANGES 5 TO 15 MIN AFTER INJECTION OF PROTAMINE

\begin{tabular}{|c|c|c|c|c|c|c|c|c|}
\hline & \multicolumn{2}{|c|}{ Before } & \multicolumn{3}{|c|}{ After $5 \mathrm{~min}$} & \multicolumn{3}{|c|}{ After $15 \mathrm{~min}$} \\
\hline & Mean & SD & Mean & SD & $\mathbf{P}$ & Mean & SD & $\mathbf{P}$ \\
\hline $\begin{array}{l}\text { Mean pulmonary artery pressure }(\mathrm{mmHg}) \\
\text { Cardiac index }\left(1 . / \mathrm{m}^{2}\right) \\
\mathrm{Qva} / \mathrm{Qt} \\
\mathrm{P}(\mathrm{A}-\mathrm{a}) \mathrm{O}_{2}(\mathrm{mmHg}) \\
\mathrm{PaO}_{2}\left(\mathrm{mmHg}^{2}\right) \\
\mathrm{PaCO}_{2}(\mathrm{mmHg}) \\
\mathrm{pH} \\
\mathrm{PvO}_{2}(\mathrm{mmHg}) \\
\mathrm{VD} / \mathrm{VT} \\
\mathrm{P}(\mathrm{a}-\mathrm{A}) \mathrm{CO}_{2}(\mathrm{mmHg}) \\
\mathrm{VO}_{\mathrm{g}}(\mathrm{ml} / \mathrm{min}) \\
\mathrm{VCO}_{2}(\mathrm{ml} / \mathrm{min})\end{array}$ & $\begin{array}{c}25 \cdot 6 \\
2 \cdot 41 \\
6 \cdot 5 \\
89 \cdot 0 \\
128 \cdot 8 \\
39 \cdot 7 \\
7 \cdot 387 \\
35 \cdot 2 \\
41 \cdot 2 \\
6 \cdot 4 \\
181 \cdot 4 \\
157 \cdot 1\end{array}$ & $\begin{array}{l}9 \cdot 5 \\
0 \cdot 90 \\
3 \cdot 2 \\
60 \cdot 4 \\
34 \cdot 7 \\
7 \cdot 4 \\
0 \cdot 057 \\
8 \cdot 0 \\
10 \cdot 8 \\
4 \cdot 8 \\
34 \cdot 4 \\
30 \cdot 4\end{array}$ & $\begin{array}{c}28 \cdot 8 \\
1 \cdot 78 \\
9 \cdot 1 \\
109 \cdot 4 \\
111 \cdot 6 \\
41 \cdot 3 \\
7 \cdot 377 \\
30 \cdot 5 \\
43 \cdot 0 \\
8 \cdot 4 \\
169 \cdot 0 \\
156 \cdot 1\end{array}$ & $\begin{array}{l}11 \cdot 4 \\
0 \cdot 88 \\
5 \cdot 4 \\
68 \cdot 7 \\
38 \cdot 1 \\
7 \cdot 3 \\
0 \cdot 067 \\
8 \cdot 4 \\
9 \cdot 7 \\
4 \cdot 9 \\
43 \cdot 4 \\
35 \cdot 2\end{array}$ & $\begin{array}{l}\text { NS } \\
\text { NS } \\
\text { NS } \\
\text { NS } \\
\text { NS } \\
\text { NS } \\
\text { NS } \\
\text { NS } \\
\text { NS } \\
\text { NS } \\
\text { NS } \\
\text { NS }\end{array}$ & $\begin{array}{c}35 \cdot 1 \\
1 \cdot 87 \\
8 \cdot 9 \\
120 \cdot 1 \\
95 \cdot 6 \\
39 \cdot 7 \\
7 \cdot 378 \\
26 \cdot 2 \\
45 \cdot 5 \\
8 \cdot 3 \\
195 \cdot 4 \\
154 \cdot 9\end{array}$ & $\begin{array}{c}11 \cdot 7 \\
0.71 \\
5 \cdot 8 \\
70 \cdot 9 \\
26 \cdot 8 \\
7 \cdot 5 \\
0.071 \\
4 \cdot 4 \\
6 \cdot 5 \\
4 \cdot 4 \\
62.7 \\
36 \cdot 1\end{array}$ & $\begin{array}{l}<0.05 \\
\text { NS } \\
\text { NS } \\
\text { NS } \\
<0.03 \\
\text { NS } \\
\text { NS } \\
<0.01 \\
\text { NS } \\
\text { NS } \\
\text { NS } \\
\text { NS }\end{array}$ \\
\hline No. of observations & \multicolumn{2}{|c|}{13} & \multicolumn{3}{|c|}{13} & \multicolumn{3}{|c|}{9} \\
\hline
\end{tabular}

direct puncture of the artery by the surgeon. Simultaneous pulmonary artery and arterial pressures were recorded immediately after blood sampling. Inspired and mixed expired oxygen concentrations were measured on a Servomex 101A paramagnetic oxygen analyser while end-tidal and mixed expired $\mathrm{CO}_{2}$ concentrations were determined with a Hartmann-Braun URAS 4 infrared analyser. Blood samples were analysed for $\mathrm{Po}_{2}, \mathbf{P C O}_{2}$, and $\mathrm{pH}$ on a Radiometer system and inspired, and mixed expired gas samples were also checked on this apparatus. The $\mathrm{O}_{2}$ content of arterial and mixed venous blood was also measured on a Lex- $\mathrm{O}_{2}$-Con apparatus which had been previously calibrated against a van Slyke apparatus. This arteriovenous $\mathrm{O}_{2}$ content difference $\left(\mathrm{CaO}_{2}-\mathrm{Cv}_{2}\right)$ was used for calculation of cardiac output by the Fick method and for the calculation of venous admixture (Q́va/Q̀t) from the equation:

$$
\frac{\dot{Q v a}}{\dot{Q} \mathrm{t}} \%=\frac{\mathrm{Cc}^{\prime} \mathrm{O}_{2}-\mathrm{CaO}_{2}}{\left.\left(\mathrm{Cc}^{\prime} \mathrm{O}_{2}-\mathrm{CaO}_{2}\right)+\left(\mathrm{CaO}_{2}-\mathrm{CV}_{2}\right)_{2}\right)}
$$

The end-pulmonary capillary-to-arterial $\mathrm{O}_{2}$ content difference $\left(\mathrm{Cc}^{\prime} \mathrm{O}_{2}-\mathrm{CaO}_{2}\right)$ was calculated from the ideal alveolar $\mathrm{PO}_{2}$ and arterial $\mathrm{Po}_{2}, \mathrm{PCO}_{2}, \mathrm{pH}$, and $\mathrm{Hb}$ using the
Severinghaus (1966) dissociation curve. All the other calculations were based on standard equations and incorporated in a computer program described by Adams (1970).

\section{RESULTS}

These are summarized in Table II.

Femoral artery pressure fell in most patients during the injection but usually returned to preinjection levels before the second sample was taken. No significant changes were therefore recorded. Pulmonary artery pressure began to increase either immediately or when the systemic pressure returned to normal levels. In some patients the increase in pressure lasted only a few minutes (Figure) but in the majority the rise in pressure outlasted the period of observations. As a result there was a significant increase in pulmonary artery pressure 15 minutes after the end of the protamine injection. Cardiac index fell but the changes did not reach significant levels. There was a significant fall in arterial oxygen 


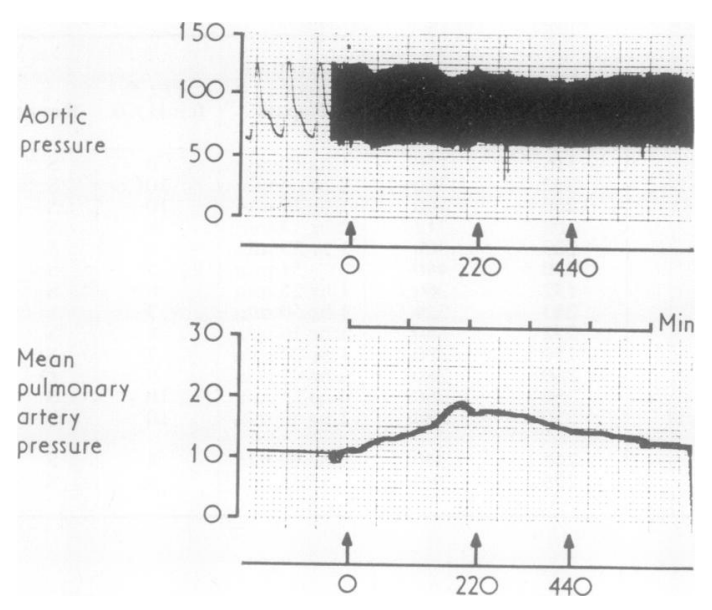

FIGURE Aortic pressure and mean pulmonary artery pressure during protamine injection. Injection started at $0 ; 220$ and 440 represent milligrams of protamine injected.

tension $\left(\mathrm{PaO}_{2}\right)$ after the injection of protamine but this was mainly due to the fall in mixed venous oxygen tension $\left(\mathrm{PvO}_{2}\right)$ since there was little change in venous admixture ( $\mathbf{Q} v a / Q t)$. There was no statistically significant change in any of the other measurements.

\section{DISCUSSION}

These results confirm previous observations that protamine produces a marked fall in cardiac output and a brief fall in systemic arterial pressure. However, it is also apparent that there is a progressive increase in pulmonary arterial pressure and that the fall in cardiac output is the main cause of the fall in arterial $\mathrm{PO}_{2}$.

It is not yet clear why cardiac output falls after protamine. Goldman, Joison, and Austen (1969) observed a depression of myocardial contractility as measured by a strain gauge sutured across the right ventricle of both heparinized and non-heparinized dogs. They also observed a decrease in the rate of rise of left ventricular pressure (dp/dt) but conditions were poorly controlled and there is therefore some doubt as to whether these changes represented a true decrease in contractility. Gourin, Streisand, and Stuckey (1971), however, measured left ventricular $\mathrm{dp} / \mathrm{dt}$ under more controlled conditions and claimed that protamine, $10 \mathrm{mg} / \mathrm{kg}$, produced, if anything, a slight positive inotropic effect. Both of these groups of authors, Jacques (1949) and Rådegran and McAslan (1972) noted that protamine produced systemic vasodilatation and portal venous congestion. Gourin et al. (1971) supported the concept that the hypotension is partly due to peripheralo pooling of blood by infusing fluid during the admini-क stration of protamine. They claimed that this $\underset{\Omega}{\square}$ prevented the occurrence of hypotension in the majority of animals.

The increase in pulmonary artery pressure in the $e^{\circ}$ presence of a reduced cardiac output suggests either $\vec{\omega}$ left ventricular failure or an increase in pulmonaryo vascular resistance. Although left atrial pressure was $\vec{x}$ not specially measured during the present observa-i tions a left atrial pressure line was commonly in place ${ }_{i r}^{\circ}$ and no obvious elevations of left atrial pressure were $c$ seen during the administration of protamine. This $\oplus$ suggests that the pulmonary hypertension was due응 to an increase in pulmonary vascular resistance.

One possible cause of an increase in pulmonary $\mathcal{D}^{\infty}$ vascular resistance is obstruction of the pulmonary vascular bed by microthrombi. Protamine produces $\frac{\mathbb{}}{3}$ a marked fall in platelet count both in vitro (Gröttum, $\mathbb{D}$ 1969; Zbinden, Mehrishi, and Tomlin, 1970) and in vivo (Perkins et al., 1961; Woods et al., 1967; $\overrightarrow{0}$ Rådegran, 1971; Rådegran and McAslan, 1972). Rådegran (1971) labelled platelets with chromium-51 O and showed that the decrease in circulating platelets following protamine injection was accompanied by an increase in platelets in the lung but not in skeletal muscle. It is therefore reasonable to suggest that the $\frac{2}{\mathbb{Q}}$ pulmonary hypertension might have been due to $\Rightarrow$ obstruction of the pulmonary vascular bed with $\frac{\text { 의 }}{3}$ microthrombi. This should have led to an increase in alveolar dead space or a-APCO${ }_{2}$ and to an increase in dead space/tidal volume ratio. However, there were no significant changes in the present studies although there must have been a marked increase in pulmonary vascular resistance. The lack of change in dead $\frac{-}{\sigma}$ space/tidal volume ratio does not necessarily rule out 3 . obstruction of the pulmonary vascular bed, for the increase in pulmonary artery pressure may have improved perfusion to previously non-perfusedo alveoli in the superior parts of the lung. This would have decreased alveolar dead space in these areas at a을. time when dead space was increasing in other parts of the lung because of obstruction by microthrombi.o

A second possible cause of the increase in pul- $N$ monary artery pressure is pulmonary vasocon- $-\tilde{\omega}$ striction. There is now a great deal of evidence tog suggest that this is the main cause of the increase in resistance and that it is due to the release of $\frac{\sim}{\mathbb{D}}$ vasoconstrictor substances from the blood or lung $\stackrel{\oplus}{?}$ tissue. An increase in pulmonary vascular resistance 0 occurs whenever platelet aggregation is induced, whether this is due to infusion of protamine, thrombin, endotoxin or to any of the other causes of $\stackrel{\Omega}{\Omega}$ disseminated intravascular coagulation (Rådegran, 1971; Swedenborg, 1971). 
Disseminated intravascular coagulation (DIC) produces an increase in respiratory rate and minute volume, pulmonary vasoconstriction, systemic vasodilatation, a low cardiac output, an increase in airway resistance, a decrease in lung compliance, and a fall in arterial oxygen tension. The magnitude of these changes is related to the fall in circulating platelets (Whitaker and McKay, 1969; Rådegran, Taylor, and Olsson, 1971) and the changes seem to be minimal in the absence of platelets (Jacques, 1949). The previous administration of acetyl salicylic acid does not affect the decrease in circulating platelets or the systemic hypotension but minimizes the changes in pulmonary artery pressure, airway resistance, lung compliance, and arterial $\mathrm{Po}_{2}$ after protamine injection (Rådegran and McAslan, 1972). Vagotomy or the previous injection of methysergide, a serotonin antagonist, does not prevent the changes induced by protamine. In view of these observations there is now some doubt as to the validity of the earlier suggestion that the pulmonary changes were mainly due to the release of serotonin while the systemic vasodilatation was due to the release of ADP and ATP from the platelets when the release reaction was initiated (Rådegran, 1971; Swedenborg, 1971). Furthermore, Jastrzebski, Hilgard, and Sykes (1974) demonstrated pulmonary vasoconstriction when protamine, protamine-heparin complex or the supernatant from this mixture was injected into the pulmonary artery of an isolated cat lung perfused with a blood-free prime. This would suggest either that protamine has a direct effect on pulmonary blood vessels or that it is capable of releasing vasoconstrictor substances from the lung itself.

Measurements of lung mechanics were not made in the present studies but the increase in venous admixture was minimal. Patterson (1972) states that measurements in man have occasionally revealed a decrease in lung compliance and an increase in airway resistance after protamine injection; similar findings have been recorded in animal experiments (Jacques, 1949; Stein, Hirose, Yasutake, and Khan, 1970; Rådegran and McAslan, 1972). Patterson showed in the dog that there was a close correlation between the changes in mechanics and the reduction in $\mathrm{CO}_{2}$ elimination following the reduction in cardiac output. He also showed that the changes could be abolished by keeping the end-tidal $\mathrm{PCO}_{2}$ constant. Rådegran and McAslan (1972) showed that intermittent hyperinflation of the lung or the application of a positive end-expiratory pressure (PEEP) abolished the changes in lung mechanics and increased arterial oxygen tension in dogs. It is possible that the application of PEEP during the present observations had similar effects, thereby minimizing changes in lung mechanics or venous admixture. It is also possible that the PEEP accentuated the fall in cardiac output after protamine. However, Seed, Sykes, and Finlay (1970) showed that there was little change in cardiac output when an end-expiratory positive pressure of $+10 \mathrm{cmH}_{2} \mathrm{O}$ was applied after cardiopulmonary bypass, and Sykes et al. (1970) showed in dogs that the application of similar pressures caused little change in cardiac output when venous pressure was high. Since the central venous pressure during the present observations was in the range $10-18 \mathrm{mmHg}$ and little change was recorded after the injection of protamine, this possibility seems unlikely.

Although the effects of protamine seem to be relatively transient in man there may be other longterm effects. It has been suggested that DIC initiated by shock may be a cause of the later pulmonary complication known as the 'shock lung' (Blaisdell, Lim, and Stallone, 1970) and it is equally possible that DIC initiated by protamine injection may lead to the later development of the post-perfusion lung syndrome (Sykes, 1969b). DIC has been shown to occur in low output states two to 10 days after open-heart surgery (Boyd, Engelman, Beaudet, and Lackner, 1972) but there is as yet no evidence that the injection of protamine is associated with delayed damage to the lung. Castaneda (1966) and Castaneda, Gans, Weber, and Fox (1967) reported that cardiopulmonary bypass could be carried out without the use of protamine and found little increase in postoperative bleeding. If lung damage is shown to occur as a result of protamine administration such a policy may have to be reconsidered.

The authors are indebted to Mr. W. P. Cleland, Professor H. H. Bentall, and the other members of the Cardiothoracic Unit who made this study possible.

\section{REFERENCES}

Adams, A. P. (1970). The effects of mechanical ventilation on gas transfer within the lung. Ph.D. Thesis, London.

Blaisdell, F. W., Lim, R. C., and Stallone, R. J. (1970). The mechanism of pulmonary damage following traumatic shock. Surgery, Gynecology and Obstetrics, 130, 15.

Boyd, A. D., Engelman, R. M., Beaudet, R. L., and Lackner, H. (1972). Disseminated intravascular coagulation following extracorporeal circulation. Journal of Thoracic and Cardiovascular Surgery, 64, 685.

Castaneda, A. R. (1966). Must heparin be neutralized following open-heart operations? Journal of Thoracic and Cardiovascular Surgery, 52, 716. 
Gans, H., Weber, K. C., and Fox, I. J. (1967). Heparin neutralization: experimental and clinical studies. Surgery, 62, 686.

Goldman, B. S., Joison, J., and Austen, W. G. (1969). Cardiovascular effects of protamine sulfate. Annals of Thoracic Surgery, 7, 459.

Gourin, A., Streisand, R. L., and Stuckey, J. H. (1971). Total cardiopulmonary bypass, myocardial contractility, and the administration of protamine sulphate. Journal of Thoracic and Cardiovascular Surgery, 61, 160.

Gröttum, K. A. (1969). Platelet surface charge and aggregation. Effects of polyelectrolytes. Thrombosis et Diathesis Haemorrhagica, 21, 450.

Jacques, L. B. (1949). A study of the toxicity of the protamine, salmine. British Journal of Pharmacology, 4, 135.

Jastrzebski, J. Hilgard, P., and Sykes, M. K. (1974). Pulmonary vasoconstriction produced by protamine and protamine-heparin complex in the isolated cat lung perfused with blood or dextran. Submitted for publication.

Pauca, A. and Sykes, M. K. (1966). The elimination of carbon dioxide after total body perfusion. British Journal of Anaesthesia, 38, 39.

Patterson, R. W. (1972). Role of carbon dioxide in changes in lung mechanics after protamine administration. Current Researches in Anesthesia and Analgesia, 51, 733.

Perkins, H. A., Harkins, G., Gerbode, F., Rolfs, M. R., and Acra, D. J. (1961). Comparison of effects of protamine and polybrene, with special emphasis on the factor VIII (anti-hemophilic globulin) deficiency induced. Journal of Clinical Investigation, 40, 1421.

Rådegran, K. (1971). Circulatory and respiratory effects of induced platelet aggregation. An experimental study in dogs. Acta Chirurgica Scandinavica, Supplement, 420.

and McAslan, C. (1972). Circulatory and ventilatory effects of induced platelet aggregation and their inhibition by acetylsalicylic acid. Acta Anaesthesiologica Scandinavica, 16, 76.

—_, Taylor, G. A., and Olsson, P. (1971). Mode of action of protamine in regard to its circulatory and respiratory side effects. European Surgical Research, 3, 139.
Seed, R. F., Sykes, M. K., and Finlay, W. E. I. (1970) The effect of variations in end-expiratory inflatio pressure on cardiorespiratory function before an after open-heart surgery. British Journal of Anaes? thesia, 42, 488.

Severinghaus, J. W. (1966). Blood gas calculator. Journa $\vec{b}$ of Applied Physiology, 21, 1108.

Stein, M., Hirose, T., Yasutake, T., and Khan, M. A $\overrightarrow{\bar{\omega}}$ (1970). The effects of platelet amines on airway function. In: Airway Dynamics, edited by Ax̣ Bouhuys, p. 283. Thomas, Springfield, Illinois. N

Swedenborg, J. (1971). On the role of vasoactive subir stances in haemodynamic changes induced bu thrombin. Acta Chirurgica Scandinavica, Supplement 413.

Sykes, M. K. (1968). A mixing device for expired gas $\vec{\sim}$ Anaesthesia, 23, 446.

(1969a). A pressure-operated collect valve fo마 respiratory studies during intermittent positive pressure ventilation. British Journal of Anaesthesiaథ 41, 189.

(1969b). Post-operative respiratory insufficiency In: Medical and Surgical Cardiology, edited by W. Cleland, J. Goodwin, L. McDonald, and D. Ross chapter 14. Blackwell Scientific Publications, Oxford Adams, A. P., Finlay, W. E. I., McCormick, P. W. and Economides, A. (1970). The effects of variations in end-expiratory inflation pressure on cardio $\frac{1}{2}$ respiratory function in normo-, hypo- and hyper volaemic dogs. British Journal of Anaesthesia, 42, 669음

Whitaker, A. N. and McKay, D. G. (1969). Induction of hypotension in Rhesus monkeys and rabbits by intravenous thrombin infusion. Laboratory Investiga tion, 20, 79.

Woods, J. E., Kirklin, J. W., Owen, C. A., Thompson J. H., and Taswell, H. F. (1967). Effects of bypas\& surgery on coagulation-sensitive clotting factors 3 . Mayo Clinic Proceedings, 42, 724.

Zbinden, G., Mehrishi, J. N., and Tomlin, S. (1970)즐

Assessment of damage to human platelets after aggregao tion and other injuries by microscopic observation? and estimation of serotonin uptake. Thrombosis ef Diathesis Haemorrhagica, 23, 261.

Requests for reprints to: Professor M. K. Sykes, Royal Postgraduate Medical School, Department of Anaes thetics, DuCane Road, London W12 0HS. 